\title{
A Tale of Two Hormones
}

\author{
Terri Foran \\ School of Women's and Children's Health, University of New South Wales \\ Royal Hospital for Women, Barker St, Randwick, Sydney 2025, New South Wales, Australia \\ t.foran@unsw.edu.au
}

\begin{abstract}
The development of the steroid hormones currently used in contraception and menopausal hormone replacement provides an interesting story in terms of brilliant research, international rivalry, major advances and sheer serendipity. This paper provides a historical perspective on the use of oestrogens and progestogens in clinical practice from the 1920s until the present day.
\end{abstract}

Keywords: History; Oestrogens; Progestogens; Menopausal Hormone Therapy; Contraception.

\section{IN THE BEGINNING....}

Modern humans share the same steroid receptors and hormones with sea sponges, jellyfish and worms - making this effective system of endocrine communication at least 500 million years old. And although plants have very different nuclear receptors, in 2010 progesterone was identified in the leaves of the walnut tree (Pauli et al., 2010). This suggests that progesterone is a truly ancient bioregulator, dating back to well before the appearance of animals.

Hormone therapy also has a longer tradition than most of us imagine. It was during the Song dynasty in $1025 \mathrm{AD}$ that Chinese physicians first described the preparation of 'autumn mineral.' About 600 litres of urine was required to provide a mere $100 \mathrm{~g}$ of this wondrous distillation (Buck, 2015). Preparation was apparently gendered, with young men providing the raw product for older males in the community and young women for older females. The regular use of 'autumn mineral' was said to maintain energy, vigour and sexual interest.

In Western medicine the concept that there were endocrine organs secreting messenger compounds into the circulation has been around since the $18^{\text {th }}$ century. However it was not until 1905 that the British physiologist Ernest Starling first coined the term 'hormone', a word derived from the Greek 'to impel or arouse' (Starling, 1905).

\section{FOLLICULIN TO OESTROGEN}

As early as 1899 the pharmaceutical company Merck was marketing pulverized cow ovaries under the tradename Ovariin ${ }^{\circledR}$ as a treatment for menopausal symptoms and menstrual problems. In the late 1920s Edward Doisy in the United States and Adolf Butenandt in Germany successfully isolated an oestrogen (at that time called 'folliculin') from the urine of pregnant women and the modern era of hormone therapy began. The German pharmaceutical company Schering first marketed oral estrone under the tradename Progynon ${ }^{\star}$, in 1928 and Ayerst in Canada countered with their variation of the same product, Emmenin ${ }^{\circledR}$ in 1930. These semi-synthetic oestrogens, though relatively expensive, were widely used in Europe and the
United States to alleviate menopausal symptoms and to 'preserve youth'.

In the 1930s Inhoffen and other German researchers (Kathol et al., 1937; Inhoffen and Hohlweg, 1938) had discovered that they could synthesise steroid hormones from a more abundant source cholesterol harvested from animal brains and spinal cords. The first oral synthetic oestrogen ethinyloestradiol was patented by Schering in 1938 under the tradename Progynon C. Diethylstilboestrol (DES), another synthetic oestrogen, was synthesized in the United Kingdom in 1938 and was at least partly developed in an attempt to counter the German dominance of steroid hormone development in the years leading up to the Second World War (Dodds et al., 1938). DES proved to be a more potent oral oestrogen than any previously available and was also relatively inexpensive since it was not patented by any pharmaceutical company. DES was later to become infamous through its association with reproductive cancers in the offspring of women who took it while pregnant. When the United States of America entered war in 1941 the government there seized control of Schering's American pharmaceutical subsidiary and Schering's hormones were made available to researchers. Though Proluton $\mathrm{C}^{\oplus}$ was not marketed in Germany until 1949, clinicians in the United States in the early 1940s were already using both ethinyloestradiol and diethylstilboestrol for the treatment of gynaecological disorders and menopausal symptoms (Frank et al., 1940; Salmone et al., 1941) The price of oestrogen therapy fell sharply in 1941 when Ayerst realised that it could more cheaply obtain oestrogens from mares' urine than from human. The availability of Premarin (Pregnant mares' urine) greatly increased the use of menopausal oestrogen therapy in the United States and Canada. It would however be many more years before the dangers of using unopposed oestrogen in older women were understood.

\section{LUTEAL HORMONE TO PROGESTOGEN}

Scientists had also been searching for an effective hormonal contraceptive. The visionary Austrian physiologist Ludwig 
Haberlandt first coined the term 'birth control (Geburtenregelung)' in 1931 (Haberlandt, 1931) though his work in this field had begun several years before with the development of a hormonal contraceptive he called Infecundin ${ }^{\circ}$. It is said that the criticism he received from colleagues as to the 'unnatural' nature of his research may have contributed to his decision to take his own life in 1932. The exact chemical structure of Infecundin ${ }^{\oplus}$ remains unclear since Haberlandt's work was never published.

Most researchers realised that the answer to effective contraception lay in the corpus luteum. Extracts from the corpus luteum were prepared and injected into experimental animals in an attempt to inhibit ovulation. These extracts were veritable hormonal soups, with proportions of the steroidal compounds varying greatly according to the tissue processed (whole ovary or only corpus luteum) and the extraction technique used. In 1934 the American gynaecologist Willard Allen finally succeeded in isolating a pure form of the hormone we now call progesterone. German and Swiss scientists were not far behind, independently publishing their findings later the same year.

Allen's luteal hormone was extremely expensive. It required the corpora lutea of 50,000 sows to produce $1 \mathrm{mg}$ of what is now called progesterone-equivalent today to a cost of around $\$ 14,000 /$ gram (Medvei, 1982; O'Dowed, 2001). Allen obtained his ovaries from his local slaughterhouse and initially used the industrial meat grinder in the kitchen of the hospital in which he worked to process his experimental material. When staff objected and refused him access he merely observed that '...our ovaries were fresher than a lot of the meat that went through that grinder...' (Komor, 2009).

In 1934 Schering was first to the market with a purified injectable progesterone they called Proluton ${ }^{\circ}$. This required intramuscular injection since unmodified progesterone is poorly absorbed orally. By this stage Schering was sourcing its reproductive hormones from massive quantities of collected human urine. From this they distilled a thick active substance called a 'Rohöl', which allowed more effective transport to its various production plants for final manufacture (Gaudillière, 2005). Proluton ${ }^{\circledR}$ was recommended for the treatment of heavy menstrual bleeding, dysmenorrhoea, recurrent miscarriage, hyperemesis gravidarum, menopausal symptoms and depression (Schlich and Tröhle, 2006). The 1930s also saw Proluton ${ }^{\circ}$ and Progynon ${ }^{\circ}$ combined cyclically to induce menses in a woman with previous amenorrhoea, with clinicians hopeful that this might provide a treatment for infertility (Kaufmann, 1932). However, despite widespread use on both sides of the Atlantic the name of this new luteal hormone had not yet been settled. Allen proposed the name 'pro-gestin' but the Europeans preferred the term 'luteosterone'. Finally, at the London Second International Conference on the Standardisation of Sex Hormones in 1935 a compromise was suggested, and the term progesterone was coined (Medvei, 1982).

The first orally active progestogen-like hormone, initially called pregneninolone, was developed by Schering in 1939 (Inhoffen et al., 1938). Later renamed ethisterone, this compound was quickly marketed as an alternative to injected progesterone under the name Proluton $C^{\varpi}$ (Kovacs, 2003; Khul, 2011). To distinguish this new type of synthetic hormone from progesterone it was termed a 'progestogen'.

The manufacture of all these semi-synthetic hormones remained a very expensive process, prompting a search for an alternative source for suitable steroid precursors.

\section{THE WORK OF RUSSELL MARKER}

At this point the renegade organic chemist Russell Marker enters the story. He was by all accounts a somewhat complex personality, and apparently had his $\mathrm{PhD}$ withheld because of a philosophical clash with his supervisor (Lehmann et al., 1973). In the 1940s he came across a paper in which Japanese researchers described the extraction of a phytosteroid called diosgenin from a wild yam species common in that country, Diascorea tokoro. Diogenin was recommended in Japan at that time for the treatment of various menstrual problems. Marker had already devised a relatively simple 5 -step process for converting a phytosteroid found in sarsaparilla into progesterone but had decided that this source was too expensive for commercial viability (Khul, 2011). He applied the same process to diosgenin and again was able to produce progesterone. Funded by the American pharmaceutical company Parke-Davis he went on to test a number of local plants for compounds similar to diosgenin and in 1942 he came across the Mexican yam- Dioscorea mexicana. This tuber can weigh as much as $100 \mathrm{~kg}$, greatly raising the potential for the extraction of marketable quantities of progesterone. Enlisting the help of a local store owner, Marker collected two large bags of the yam which had to be smuggled back to America because he lacked any export licence.

Since Parke-Davis had provided him with the original capital Marker approached them on his return with a view to commercialising the process. The company refused, though the reasons for the refusal remain controversial. Some say that the company believed the venture was non-viable (Lehmann et al., 1973) while others contend it was because Marker refused to sign the patent for the process over to them. By late 1942, after being turned down by several pharmaceutical companies, Marker made the decision to manufacture the product himself. He collected another 10 ton of tubers and employed a local coffee merchant to convert these into syrup for easier transport. In a borrowed laboratory, Marker was able to produce $3 \mathrm{~kg}$ of top-quality progesterone (Lehmann et al., 1973). The value of this first production run would have been about $\$ 3.5$ million in today's dollars.

In 1944 Marker and two business partners established a company called Syntex and within a year progesterone was available at $\$ 50$ a gram. A dispute saw Marker leave the company on bad terms in 1945. He set up his own pharmaceutical company, Botanica-Mex, but was subsequently sued by Syntex for 'stealing their process'. Undeterred, he found another tuber 'Barbasco' which had five times more diosgenin than the original and went on to synthesise not only progesterone but several other steroid hormones and corticosteroids from the basic extracted plant sterols (Lehmann et al., 1973). Marker later sold his company and devoted himself to commissioning Mexican-made replicas of antique European silverwork. At age 85, eight years before his death, he was finally awarded an honorary Doctorate. By 1955, 80-90\% of all steroid hormone synthesis began with the Barbasco yam (Marks, 2001).

\section{STEROID HORMONES FOR MENOPAUSE MANAGEMENT AND CONTRACEPTION}

In the 1950s both oestrogens and testosterone were widely used in menopausal hormone therapy (Schering Corporation - YouTube, 2017). It was known that progesterone could suppress ovulation but because it required daily injection it held little appeal as a long-term contraceptive method. Schering's oral progestogen, ethisterone, unfortunately had a significant rate of androgenic side-effects which limited its value except for short-term use.

In the flurry of steroid research which characterised the early 1950s a number of orally active progesterone-like substances had already been synthetized. Though initially developed as treatments for gynaecological conditions, such as menstrual irregularities and endometriosis, it was soon apparent that these compounds might also have a role as potential oral contraceptives. In 1951 Carl Djerassi and the group working at Syntex produced 19-nor-17a-ethyltestosterone. 
This synthetic hormone was chemically very similar to the ethisterone developed 12 years earlier in Germany but differed critically in the absence of the methyl group at the 19 position of the steroid ring. This resulted in an orally active compound which was not only several times more potent than natural progesterone but also had a tolerable side effect profile in clinical trials. This new compound was the first of many such nor-steroids used in oral contraception and Syntex called it norethindrone. Outside the United States it was named norethisterone in recognition of its predecessor and it is still used today in contraceptive pills.

Norethisterone was one of three progestogens selected by Gregory Pinkus for the original oral contraceptive pill trials - the other two being Searle's norethynodrel and norethandrolone which were both synthesized in 1952 (Speroff, 2009). Interestingly with the development of these compounds Willard Allen finally got his way with regard to terminology. While the rest of the world referred to both progesterone and its synthetic analogues as 'progestogens', the United States adopted the word 'progestin' specifically for these synthetic progesterone-like hormones.

\section{THE DEVELOPMENT OF THE ORAL CONTRACEPTIVE PILL}

Pincus and the fertility specialist John Rock conducted their first trials on nurses in the Massachusetts General Hospital in Boston where Rock worked. They initially compared oral, vaginal and injectable forms of all three progestogens for efficacy and side effects (Pincus, 1955). It was a requirement that all subjects enrolled in these early trials were infertile since contraceptive research was illegal in the State at that time. As larger efficacy trials rolled out however, the research trials needed to relocate outside the United States, mainly to Puerto Rico. Norethynodrel had already been judged as the most promising contender in terms of ovulation suppression and side effects but then a critical accident occurred. A flaw in the production process meant that a small amount of the synthetic oestrogen mestranol contaminated the norethynodrel. Subsequent efforts to 'purify' the norethynodrel resulted in greater rates of irregular bleeding. With this realisation the role of oestrogen in endometrial stabilisation was appreciated and combined oral contraceptive pill was born.

Even after the success of the early trials most American pharmaceutical companies refused to market the contraceptive Pill because they feared a backlash from Catholic and conservative groups (Marks, 2001). Searle however tested the waters in 1957 by registering a combination of mestranol and norethynodrel for the treatment of gynaecological disorders. This same product, Enovid ${ }^{\oplus}$, was finally marketed explicitly for contraceptive purposes three years later. Other pharmaceutical companies on both sides of the Atlantic quickly followed with their own combined contraceptive preparations.

\section{PROGESTOGENS AND MENOPAUSAL HORMONE THERAPY}

It would be several years before the paths of the various hormones used in contraception and menopause management crossed again. By the mid-1970s it was becoming apparent that the traditional use of unopposed oestrogen in menopausal women also increased their risk of endometrial hyperplasia and endometrial cancer (Zeil and Finkl, 1975). At this point the synthetic progestogens initially developed for contraceptive use were tentatively introduced into menopausal hormone therapy in the United States - most commonly medroxyprogesterone acetate and to lesser extent norethisterone and levonorgestrel (Campagnoli et al., 1975). The uptake of combination menopausal hormone therapy in America was initially slow - with only $5 \%$ on combined therapy in 1980 and 12\% in 1983 (Kennedy et al., 1985). Eventually however the use of a progestogen in menopausal hormone therapy was deemed essential for women who had not had a hysterectomy, reflecting the approach European clinicians had adopted somewhat earlier. The main problem for clinicians on both sides of the Atlantic was that many of the side effects ascribed to combined menopausal hormone therapy can in fact be attributed to the progestogen component.

The use of medroxyprogesterone acetate for menopausal hormone therapy was less common in Europe since clinicians there believed that it was associated with a greater incidence of progestogenic side effects. In northern Europe norethisterone acetate was the most common choice while in southern and central Europe cyproterone acetate, dydrogesterone, nomegestrol acetate and promegestone were also widely used (Campagnoli et al., 1975). In the early 1980s however, the ability to micronise progesterone so that oral or vaginal absorption of the compound became significantly more reliable led to the increasing use of progesterone itself in menopausal hormone therapy, particularly in France (Campagnoli et al., 1975). Since progesterone is associated with fewer side effects than synthetic progestogens, the use of micronised progesterone in combination menopausal hormone therapy is now increasing across the world.

And to complete the circle, progesterone now plays a role in contraception as well. Progesterone vaginal rings such as Progering ${ }^{\oplus}$ are now marketed in some countries for contraceptive use for up to six months postpartum (Carr et al., 2016). These deliver a constant $10 \mathrm{mg}$ progesterone per day over their three-month life-span and have an efficacy of $98.5 \%$ provided the mother is fully breastfeeding. The use of progesterone rather than a synthetic progestogen in such devices may hold an additional appeal for some mothers since although it is found in breast milk it is poorly absorbed by the infant's gut.

\section{IN CONCLUSION}

The ability to synthesise ovarian hormones has revolutionised the way that both women and clinicians view reproductive choice and menopause management. As the result of the efforts of clinicians and scientists from the 1920s until the present day, there are now a wide range of different steroid hormones, both synthetic and bodyidentical, from which to choose.

\section{REFERENCES}

Buck C. Acupuncture and Chinese Medicine: Roots of Modern Practice. London (UK): Singing Dragon; 2015: p. 180.

Campagnoli C, Clavel-Chapelon F, Kaaks R, et al. Progestins and progesterone in hormone replacement therapy and the risk of breast cancer. J Steroid Biochem Mol Biol. 2005;96(2):95-108.

Carr SL, Gaffield ME, Dragoman MV, et al. Safety of the progesteronereleasing vaginal ring (PVR) among lactating women: A systematic review. Contraception. 2016;94(3):253-61.

Dodds EC, Goldberg L, Lawson W, et al. Estrogenic activity of certain synthetic compounds. Nature. 1938;141(3562):247-8.

Frank RT, Goldberger MA, Felshin G. Clinical and labotratory investigations of some of the newer sex hormone preparations. Endocrinology. 1940;27:381-4.

Gaudillière JP. Better prepared than synthesized: Adolf Butenandt, Schering AG and the transformation of sex steroids into drugs (1930-1946). Studies in History and Philosophy of Biological and Biomedical Sciences. 2005;36:612-44.

Haberlandt L. Die hormonale Sterilisierung des weiblichen Organismus [The hormonal sterilization of the female organism.] 
Monatsschrift für Geburtshilfe und Gynäkologie. 1931;87:320-32. German.

Inhoffen $\mathrm{HH}$, Hohlweg W. Neue per os-wirksame weibliche Keimdrüsenhormon-Derivate: 17-Aethinyl-oestradiol und Pregnen-in-on-3-ol-17. [New orally effective female germ-gland hormone derivatives: 17-ethynyl oestradiol and pregnen-in-on3-ol-17] Die Naturwissenschaften. 1938;26(6):96. German.

Inhoffen HH, Logemann W, Hohlweg W, et al. Untersuchungen in der sexualhormon-Reihe [Investigations in the Sexual Hormone Series] Chem Ber. 1938;71:1024-32. German.

Kathol J, Logemann W, Serini A. Ein Übergang aus der AndrostanReihe in die Pregnan-Reihe. [A transition from the androstane series to the pregnane series.] Die Naturwissenschaften. 1937;25: 682. German.

Kaufmann C. Über die Therapie ovarieller Störungen mit Hormonen der Keimdrüse. [About the therapy of ovarian disorders with hormones of the gonad]. Med Klin. 1932;11:955-7. German.

Kennedy D, Baum C, Forbes MB. Non contraceptive oestrogens and progestins: Use patterns over time. Obstet Gynecol. 1985;65;441-6.

Khul HJ. Pharmacology of progestogens. J Reprod Med Endocrinol. 2011;8(Special Issue 1):157-77.

Komor AJ. Perspectives on the History of Oral Contraceptives: Popular, Progesterone and Personal. [Honours Thesis]. Middletown (CT): Wesleyan University; 2009: p. 41.

Kovacs G. Pharmacology of progestogens used in oral contraceptives: An historical review to contemporary prescribing. ANZJOG. 2003;43(1):4-9.

Lehmann PA, Bolivar A, Quintero R, Russell E. Marker. Pioneer of the Mexican steroid industry. J Chem Educ. 1973;50(3): 195-9.
Marks LV. Sexual Chemistry: A History of the Contraceptive Pill. New Haven (CT): Yale University Press; 2001. p. 64.

Medvei VC. A History of Endocrinology. Lancaster (UK): MTP Press Limited Falcon House; 1982: p. 402.

O’Dowd M. The History of Medications for Women. Nashville (TN): Parthenon Publishing Co; 2001: p. 345-6.

Pauli GF, Friesen JB, Gödecke T, et al. Occurrence of progesterone and related animal steroids in two higher plants. J Nat Prod. 2010;73(3):338-45.

Pincus GG. Some effects of progesterone and related compounds upon reproduction and early development in mammals. In: Proceedings of the $5^{\text {th }}$ International Conference on Planned Parenthood, Tokyo. Japan, 1955: p. 175-84.

Salmon UJ, Geist SH, Walter RI, et al. Therapeutic effectiveness of orally administered ethinylestradiol. J Clin Endocrinol. 1941;1:556-8.

Schering Corporation, Bloomfield(NJ). The Menopause: Its Significance and Management. https:/www.youtube.com/ watch?v=HhxgxsT5zLU. Accessed September 2017.

Schlich T, Tröhle U. The Risks of Medical Innovation. London (UK): Routledge; 2006: p. 149.

Speroff L. A Good Man: Gregory Goodwin Pincus: The Man, His Story, The Birth Control Pill. Portland (OR): Arnica Publishing; 2009: p. 168.

Starling EH. The chemical correlation of the functions of the body, Lecture I. Lancet. 1905;2:339-41.

Zeil HK, Finkl WD. Increased risk of endometrial carcinoma amongst users of conjugated oestrogens. N Engl J Med. 1975; 293:1167-70. 